Sport Science: Jurnal Sain Olahraga dan Pendidikan Jasmani ISSN 114-562X (Cetak), ISSN XXXX-XXXX(Online)

http://sportscience.ppj.unp.ac.id/index.php/jss/index

\title{
Studi Tentang Perilaku Hidup Sehat Siswa Sekolah Dasar Negeri 09 Air Tawar Padang
}

\author{
Syahrastani ${ }^{1}$, Yogi Andria ${ }^{2}$, Pitnawati ${ }^{3}$ \\ ${ }^{123}$ Fakultas Ilmu Keolahragaan, Universitas Negeri Padang, Indonesia. \\ E-mail: syahrastani@yahoo.com ${ }^{1}$, yogiandria@fik.unp.ac.id², pitnawati@fik.unp.ac.id ${ }^{3}$
}

\begin{abstract}
Abstrak
Masalah dalam penelitian ini berawal dari masih banyak siswa yang kurang menerapkan perilaku hidup sehat di SD Negeri 09 Air Tawar Barat Kec. Padang Utara Kota Padang. Tujuan penelitian ini adalah untuk mendeskripsikan atau menggambarkan tentang perilaku hidup sehat siswa di SD Negeri 09 Air Tawar Barat Kec. Padang Utara Kota Padang yang terdiri dari perilaku menjaga kesehatan pribadi, perilaku mencuci tangan dengan air yang mengalir dan memakai sabun, perilaku mengkonsumsi makanan jajanan yang bersih dan sehat, perilaku menggunakan jamban yang bersih dan sehat, perilaku berolahraga yang teratur dan terukur, perilaku memberantas jentik nyamuk, perilaku tidak merokok di sekolah, perilaku menimbang berat badan dan mengukur tinggi badan setiap bulan, perilaku membuang sampah pada tempatnya.

Jenis penelitian ini adalah deskriptif yaitu penelitian yang menggambarkan apa adanya tentang sesuatu variabel, gejala atau keadaan tertentu. Populasi dalam penelitian ini adalah seluruh siswa di SD Negeri 09 Air Tawar Barat Kec. Padang Utara Kota Padang yang berjumlah 170 orang siswa. Penarilakan sampel dilakukan secara purposive sampling yaitu siswa kelas IV dan V yang berjumlah sebanyak 54 orang siswa. Pengumpulan data dilakukan dengan penyebaran angket kepada responden kemudian data tersebut diolah dengan menggunakan rumus distribusi frekuensi atau teknik persentase.

Berdasarkan hasil penelitian yang telah dilakukan di SD Negeri 09 Air Tawar Barat Kec. Padang Utara Kota Padang tentang studi perilaku hidup bersih dan sehat siswa di sekolah tersebut secara umum dapat disimpulkan bahwa Studi Tentang Perilaku Hidup Bersih dan Sehat Siswa di SD Negeri 09 Air Tawar Barat Kec. Padang Utara Kota Padang dengan persentase 68,25\% berada pada kategori cukup. Hal ini berarti siswa masih kurang menerapkan perilaku hidup sehat di sekolah tersebut, sehingga masih perlu ditingkatkan lagi.
\end{abstract}

Kata Kunci: Prilaku Hidup Sehat, Siswa

\begin{abstract}
Problem in this research started from still many students who do not apply healthy living behavior in the primary elementary school 09 West Freshwater Kec. Padang Utara City. The purpose of this research is to describe or describe the healthy life behavior of students in the primary elementary school 09 West Freshwater Kec. Padang Utara Padang, consisting of behavior of maintaining personal health, the behavior of washing hands with water flowing and wearing soap, the behavior of consuming clean and healthy hawker food, behavior using a clean and healthy latrines, regular and measurable exercise behavior, the behavior of combating mosquito repellent, the behavior of not smoking in school, behavior weighing weight and measuring the height of each month, the behavior of throwing waste into place.

This type of research is a descriptive research that describes what it is about a particular variable, symptom or circumstance. The population in this study is all students in the elementary school 09 West Freshwater region Kec. Padang Utara City, amounting to 170 students. Sampling is done in purposive sampling i.e. grade IV and V students totalling 54 students. Data collection is done by distributing the poll to the respondent then the data is processed using a frequency distribution formula or percentage technique.
\end{abstract}


Based on the results of research that has been done in elementary school 09 West Freshwater Kec. Padang Utara City about the study of the behavior of clean and healthy life of students in the school can generally be concluded that the study of the conduct of clean and healthy living students in public ELEMENTARY 09 West Freshwater Kec. Padang Utara City with a percentage of $68.25 \%$ is in the category enough. This means that students are still lacking in healthy living behavior in the school, so they need to be improved again.

Keywords: Attitude of healthy life, Students

\section{PENDAHULUAN}

Pengembangan kemampuan psikomotor ini dapat dilakukan melalui proses pembelajaran pendidikan jasmani, olahraga dan kesehatan (penjasorkes). Penjasorkes tidak hanya bertujuan untuk mengembangkan kemampuan psikomotor siswa tetapi juga memberikan pengetahuan tentang pendidikan kesehatan, seperti kesehatan pribadi, kebersihan lingkungan dan lain sebagainya. Sekolah dasar merupakan salah satu institusi dari program pendidikan wajib belajar sembilan tahun. Dan sekolah dasar (SD) merupakan dasar dalam memberi pengetahuan kognitif dan afektif maupun psikomotor. Untuk mencapainya dapat dilakukan di sekolah untuk mencapai siswa yang berkualitas sesuai dengan tujuan pendidikan SD yaitu memberi bekal kemampuandasar yang bermanfaat bagi siswa untuk mempersiapkan mereka mengikuti pendidikan selanjutnya.

Pendidikan kesehatan di sekolah juga dapat dilakukan melalui pendekatan usaha kesehatan sekolah (UKS). Keberadaan UKS sangatlah bermanfaat. Unit ini bisa menjadi sarana kesehatan di sekolah. Siswa diberi pelajaran tentang cara menjaga kebersihan diri dan lingkungan. Dengan kata lain, UKS juga berperan penting dalam pendidikan kesehatan karena dalam pembelajaran kesehatan UKS sangat menunjang dalam penerapan ilmu kesehatan bagi siswa dalam kehidupan sehari-hari.

Penanaman nilai-nilai perilaku hidup sehat di sekolah tersebut tidak hanya menjadi perhatian guru saja tetapi peranan kepala sekolah, dan para orang tua juga sangat dibutuhkan. Dengan adanya perhatian kepala sekolah terhadap peningkatan perilaku hidup sehat siswa disekolahnya diharapkan para siswa lebih dapat meningkatkan perilaku hidup sehat di sekolah. Orangtua diharapkan dapat memberikan contoh teladan yang baik kepada anak-anaknya tentang prilaku hidup sehat, karna anak usia sekolah masih membutuhkan didikan dan dorongan dari orang tuanya.Guru sebagai pendidik juga harus lebih berperan aktif dalam meningkatkan perilaku hidup sehat para siswanya. Guru diharapkan tidak hanya fokus terhadap proses belajar mengajar. Tetapi juga memperhatikan perilaku hidup sehat siswanya demi mendapatkan kelancaran proses belajar mengajar.

Berdasarkan observasi yang dilakukan pada bulan September2012 di SD Negeri 09 Air Tawar Barat Kecamatan Padang Utara Kota Padang, ternyata masih banyak siswa yang kurang menerapkan PHBS di sekolah tersebut, seperti tidak menjaga kesehatan pribadi, tidak mencuci tangan dengan air yang mengalir dan memakai sabun, tidak mengkonsumsi makanan jajanan yang sehat di kantin sekolah, tidak menggunakan jamban yang bersih dan sehat,olahraga yang tidak teratur dan terukur, tidak memberantas jentik nyamuk, merokok di sekolah, tidak menimbang berat badan dan mengukur tinggi badan setiap bulan, membuang sampah tidak pada tempatnya.Dari gejala di atas, diduga karna belum jalannya penerapan perilaku hidup sehat siswa di sekolah di SD Negeri 09 Air Tawar Barat Kec. Padang Utara Kota Padang.

Adapun perilaku hidup bersih dan sehat di sekolah yang ditekankan dalam penelitian ini adalah tentang perilaku menjaga kesehatan pribadi, perilaku mencuci tangan dengan air yang mengalir dan memakai sabun, perilaku mengkonsumsi makanan jajanan yang bersih dan sehat, perilaku menggunakan jamban yang bersih dan sehat, perilaku melakukan olahraga yang teratur dan terukur, perilaku memberantas jentik nyamuk, perilaku tidak merokok di sekolah, perilaku mengukur tinggi dan berat badan di sekolah setiap bulan, dan perilaku membuang sampah pada tempatnya.

\section{METODE}


Berdasarkan permasalahan dan tujuan penelitian yang telah ditetapkan, maka penelitian ini merupakan penelitian deskriptif. Menurut A. Muri Yusuf (2005:87),"penelitian deskriptif adalah salah satu jenis penelitian yang bertujuan mendeskripsikan secara sistematis, faktual dan akurat mengenai fakta- fakta dan sifat populasi dan mencoba menggambarkan secara detail".

Maksud kutipan diatas dikaitkan dengan penelitian ini dapat dijelaskan bahwa masalah yang ingin dipecahkan dalam penelitian ini berlangsung pada masa sekarang, yakni masih banyaknya siswa yang belum menjaga kebersihan pribadi, penelitian ini dimaksudkan untuk mendeskripsikan atau mengungkapkan kebiasaan berperilaku hidup sehat dari hasil belajar penjasorkes pada siswa.

Penelitian ini dilakukan di SD Negeri 09 Air Tawar Barat Kec. Padang Utara Kota Padang Populasi akan memberikan gambaran yang tepat tentang berbagai kejadian, namun dalam jumlah yang besar, daerah yang luas dan variasi yangbanyak akan membutuhkan biaya yang banyak dan waktu yang banyak. Menurut Suharmi Arikunto (2006:102), "populasi adalah keseluruhan subyek penelitian".

Dari kutipan tersebut dapat dijelaskan bahwa populasi merupakan sekumpulan obyek yang ingin diteliti yang mengandung informasi yang ingin diketahui.Adapun populasi dalam penelitian ini adalah seluruh siswa dari kelas I (satu) sampai dengan kelas VI (enam) di SD Negeri 09 Air Tawar Barat Kec. Padang Utara Kota Padang yang berjumlah 170 orang yang terdiri dari 94 siswa laki-laki dan 76 orang siswa perempuan. Sampel merupakan bagian dari populasi yang akan diteliti.Sampel dalam penelitian ini dibatasi pada siswa kelas IV dan kelas V di SD Negeri 09 Air Tawar Barat Kec. Padang Utara Kota Padang yang berjumlah sebanyak 54 orang siswa.

Penarikan sampel dilakukan dengan teknikpurposive sampling. Menurut Riduwan (2006:63) "purposive sampling adalah teknik sampling yang digunakan peneliti jika peniliti mempunyai pertimbangan-pertimbangan tertentu di dalam pengambilan sampel atau penentuan sampel untuk tujuan tertentu".Adapun pertimbangan atau maksud penulis menetapkan sampel adalah: (1) siswa kelas IV dan kelas V sudah mulai berperilaku hidup sehat dalam kehidupan sehari-hari, (2) siswa kelas IV dan kelas V dianggap sudah lebih memahami pernyataan-pernyataan dalam angket penelitian, (3) siswa kelas IV dan kelas V telah mempelajari semua indikator penelitian ini dalam mata pelajaran penjasorkes, (4) siswa kelas VI tidak dilibatkan dalam penelitian ini karenawaktu penelitian berdekatan dengan ujian nasional, (5) siswa kelas I, II dan IIItidak dilibatkan karena dianggap belum memahami pernyataan-pernyataan dalam angket penelitian.

\section{Teknik dan Alat Pengumpulan Data}

Teknik pengumpulan data yang digunakan dalam penelitian ini adalah metode angket (kuisioner). Menurut Riduwan (2006:71), "angket adalah daftar pernyataan yang diberikan kepada orang lain bersedia memberikan respons (responden) sesuai dengan permintaanpengguna".Pendapat ini mengemukakan bahwa metode angket (kuisioner) merupakan metode pengumpulan data dengan cara memberikan pertanyaan atau pernyataan tertulis yang relevan dengan tujuan penelitian.

Untuk memperoleh data mengenai Studi Tentang Perilaku Hidup Sehat Siswa di SD Negeri 09 Air Tawar Barat Kec. Padang Utara Kota Padang, alat yang digunakan untuk mengumpulkan data tersebut adalah berupa angket yang disebarkan kepada siswa. Adapun langkah-langkah yang dilakukan adalah sebagai berikut:

1. Menyusun angket

Angket yang disusun berdasarkan indikator dari masalah yang diteliti atau menetapkan kisi-kisi angket. Angket yang digunakan merupakan angket tertutup (angket berstruktur), yaitu angket yang disajikan dalam bentuk pertanyaan atau pernyataan dan responden diminta untuk memelih salah satu jawaban yang tersedia. Skala pengukuran yang digunakan adalah skala guttman dengan dua alternatif jawaban, yaitu"Ya" dan "Tidak". Sebagaimana yang diungkapkan Riduwan (2006:91) bahwa, "skala guttman adalah skala yang digunakan untuk jawaban yang bersifat jelas (tegas)dan konsisten". 
Jawaban responden dapat berupa skor tertinggi bernilai satu (1) pada jawaban "Ya" dan skor terendah bernilai nol (0) pada jawaban "Tidak".

2. Melakukan uji coba angket

Uji coba angket dilakukan kepada yang bukan sampel penelitian dan melakukan perbaikan terhadap angket uji coba tersebut.

3. Penyebaran angket

Angket disebarkan kepada sampel penelitian ini, yaitu siswa kelas IV dan kelas siswa V SD Negeri 09 Air Tawar Barat Kecamatan Padang Utara Kota Padang yang berjumlah 54 orang siswa. Setelah itu angket di kumpulkan kembali, dan mengolah data mentah hasil penelitian.

\section{Teknik Analisis Data}

Teknik analisa yang digunakan dalam penelitian ini adalah dengan menggunakan teknik tabulasi frekuensi (statistik deskriptif) dengan perhitungan persentase (\%), seperti yang dijelaskan Sudjana (1991:40), bahwa "bila suatu penelitian bertujuan untuk mendapatkan gambaran atau menemukan sebagaimanaadanya tentang sesuatu obyek yang diteliti maka teknik analisis data yang dibutuhkan cukup dengan perhitungan persentase".

\section{HASIL DAN PEMBAHASAN \\ Hasil Penelitian}

Deskripsi data dan pembahasan hasil penelitian sesuia dengan pernyataan penelitian yang diajukan. Sebelum dilakukan analisis terhadap "Studi Tentang Perilaku Hidup Bersih dan Sehat Siswa di SD Negeri 09 Air Tawar Barat Kec. Padang Utara Kota Padang” yang ditinjau dari aspek perilaku hidup sehat diswa di sekolah, yakni perilaku menjaga kesehatan pribadi, perilaku mencuci tangan dengan air yang mengalir dan memakai sabun, perilaku mengkonsumsi makanan jajanan yang bersih dan sehat, perilaku menggunakan jamban yang bersih dan sehat, perilaku berolahraga yang teratur dan terukur, perilaku memberantas jentik nyamuk, perilaku tidak merokok di sekolah, perilaku menimbang dan mengukur tinggi badan setiap bulan, dan perilaku membuang sampah pada tempatnya, maka dilakukan verifikasi (seleksi) terhadap data yang telah diperoleh.

Tujuan dilakukan verifikasi data adalah apabila ada data yang tidak lengkap yang diisi oleh responden dalam instrument, maka data tersebut dapat diolah. Kriteria lengkapnya data yang diisi responden terhadap instrumen, apabila seluruh pertanyaan dijawab sesuai dengan instruksi yang ada dalam instrument tersebut. Berdasarkan hasil verifikasi terhadap data yang diperoleh, ternyata semua data dapat diolah. Untuk lebih jelasnya dapat di uraikan sebagai berikut:

\section{Perilaku Menjaga Kesehatan Pribadi}

Mengenai perilaku menjaga kesehatan pribadi siswa di sekolah di SD Negeri 09 Air Tawar Barat Kec. Padang Utara Kota Padang penulis memberikan 10 butir pertanyaan dilihat dari 4 (empat) indikator, yaitu perilaku tentang menjaga kesehatan gigi, perilaku tenyang menjaga kesehatan kulit, perilaku tentang menjaga kebersihan kuku, dan perilaku tentan menjaga kebersihan pakaian.

Hasil Analisis data dapat diuraikan menunjukkan tentang perilaku menjaga kesehatan pribadi siswa. Pertanyaan no 1 sebanyak $37(68,52 \%)$ orang siswa menjawab "ya" dan $17(31,48 \%)$ orang siswa menjawab "tidak", pertanyaan no 2 sebanyak 19 (35,19\%) orang siswa menjawab "ya" dan 35 $(64,81 \%)$ orang siswa menjawab "tidak", pertanyaan no 3 sebanyak $54(100 \%)$ orang siswa menjawab "ya" dan tidak ada siswa yang menjawab "tidak", pertanyaan no 4 sebanyak $53(98,15 \%)$ orang menjawab "ya" dan $1(1,85 \%)$ orang menjawab "tidak", pertanyaan no 5 sebanyak $43(79,63 \%)$ orang siswa menjawab "ya" dan $11(20,37)$ orang menjawab "tidak", pertanyaan no 6 sebanyak $46(85,185 \%)$ orang siswa menjawab "ya" dan $8(14,81 \%)$ orang siswa yang menjawab "tidak", pertanyaan no 7 sebanyak $46(85,185 \%)$ orang menjawab "ya" dan $8(14,81 \%)$ orang menjawab "tidak", pertanyaan no 8 dan 9 sebanyak 54 (100\%) orang siswa menjawab "ya" dan tidak ada siswa yang menjawab "tidak", 
dan pertanyaan no 10 sebanyak $36(66,67 \%)$ orang menjawab "ya" dan $18(33,33 \%)$ orang menjawab "tidak".

Berdasarkan analisis di atas, maka dapat disimpulkan hasil distribusi frekuensi data tentang perilaku menjaga kesehatan pribadi siswa dari 54 orang responden untuk 10 butir pernyataan, jumlah skor jawaban "ya" adalah 442 atau dengan jumlah rata-rata persentase $81,9 \%$ dan jumlah skor jawaban "tidak" adalah 98 atau dengan jumlah rata-rata persentase $18,1 \%$. Berdasarkan hasil yang diperoleh maka dapat disimpulkan bahwa perilaku siswa dalam menjaga kesehatan pribadi tergolong baik, yakni dengan rata-rata persentase $81,9 \%$. Untuk lebih jelasnya perilaku tentang menjaga kesehatan pribadi siswa di SD Negeri 09 Air Tawar Barat Kec. Padang Utara Kota Padangdapat dilihat pada gambar histogram di bawah ini:

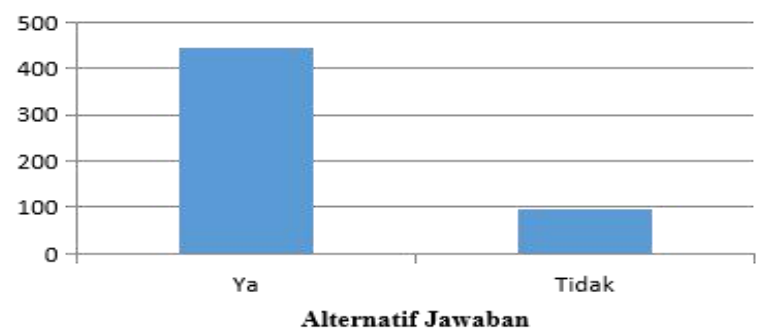

Gambar 1. Perilaku Tentang Menjaga Kesehatan Pribadi

\section{Perilaku Tentang Mencuci Tangan dengan Air yang Mengalir dan Memakai Sabun}

Mengenai perilaku mencuci tangan dengan air yang mengalir dan memakai sabun di sekolah di SD Negeri 09 Air Tawar Barat Kec. Padang Utara Kota Padang penulis memberikan 5 butir pertanyaan dilihat dari 3 (tiga) indikator, yaitu perilaku mencuci tangan, alat yang digunakan untuk mencuci tangan, dan cara mencuci tangan.

Berdasarkan analisisa data deskriptif menunjukkan tentang perilaku mencuci tangan dengan air yang mengalir dan memakai sabun. Pertanyaan no 11 sebanyak 51 (94,44\%) orang siswa menjawab "ya" dan $3(5,56 \%)$ orang siswa yang menjawab "tidak", pertanyaan no 12 sebanyak $27(50 \%)$ orang menjawab "ya" dan $27(50 \%)$ orang menjawab "tidak", pertanyaan no 13 sebanyak $49(90,74 \%)$ orang siswa menjawab "ya" dan $5(9,26 \%)$ orang siswa yang menjawab "tidak", pertanyaan no 14 sebanyak $24(44,44 \%)$ orang siswa menjawab "ya" dan $30(55,56 \%)$ orang siswa yang menjawab "tidak", dan pertanyaan no 15 sebanyak $43(79,63 \%)$ orang menjawab "ya" dan $11(20,37 \%)$ orang menjawab "tidak".

Berdasarkan analisis di atas, maka dapat disimpulkan hasil distribusi frekuensi data tentang perilaku mencuci tangan dengan air yang mengalir dan memakai dari 54 orang responden untuk 5 butir pernyataan, jumlah skor jawaban "ya" adalah 194 atau dengan jumlah rata-rata persentase $71,85 \%$ dan jumlah skor jawaban "tidak" adalah 76 atau dengan jumlah rata-rata persentase $28,15 \%$. Berdasarkan hasil yang diperoleh maka dapat disimpulkan bahwa perilaku siswa dalam mencuci tangan dengan air yang mengalir dan memakai sabun di SD Negeri 09 Air Tawar Barat Kec. Padang Utara Kota Padang tergolong cukup, yakni dengan rata-rata persentase 71,85\%. Untuk lebih jelasnya perilaku tentang mencuci tangan dengan air yang mengalir dan memakai sabun di SD Negeri 09 Air Tawar Barat Kec. Padang Utara Kota Padangdapat dilihat pada gambar histogram di bawah ini:

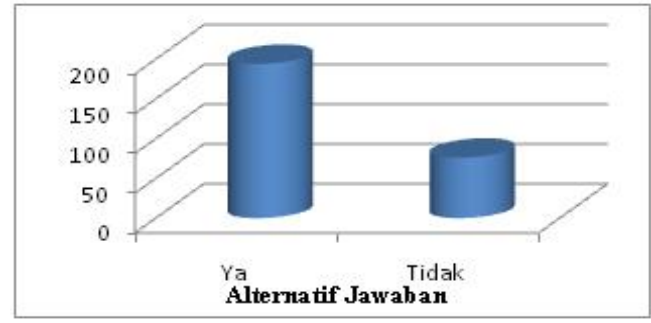

Gambar 2. Perilaku Tentang Mencuci Tangan Dengan Air yang Mengalir dan Memakai Sabun 


\section{Perilaku Mengkonsumsi Makanan Jajanan yang Bersih dan Sehat}

Mengenai perilaku menjaga kebersihan dan kesehatan makanan jajanan di sekolah di SD Negeri 09 Air Tawar Barat Kec. Padang Utara Kota Padang dilihat dari 2 (dua) indikator, yaitu menjaga tempat kebersihan makanan jajanan, dan memilih makanan jajanan yang bersih dan sehat. Selanjutnya hasil analisis data menunjukkan tentang perilaku mengkonsumsi makanan jajanan yang bersih dan sehat. Pertanyaan no 16 sebanyak $32(59,26 \%)$ orang siswa menjawab "ya", dan $22(40,74 \%)$ orang siswa menjawab "tidak", pertanyaan no 17 sebanyak $53(98,15 \%)$ orang siswa yang menjawab "ya", dan $1(1,85 \%)$ orang siswa menjawab "tidak", pertanyaan no 18 sebanyak $40(47,074 \%)$ orang siswa menjawab "ya" dan $14(25,93 \%)$ orang menjawab "tidak", pertanyaan no 19 sebanyak $43(79,63 \%)$ orang siswa menjawab "ya" dan $11(20,37 \%)$ orang siswa yang menjawab "tidak", dan pertanyaan no 20 sebanyak 40 (74,07\%) orang menjawab "ya" dan 14 (25,93\%) orang menjawab "tidak".

Berdasarkan analisis di atas, maka dapat disimpulkan hasil distribusi frekuensi data siswa tentang perilaku mengkonsumsi makanan jajanan yang bersih dan sehat 54 orang responden untuk 5 butir pernyataan, jumlah skor jawaban "ya" adalah 208 atau dengan jumlah rata-rata persentase $77,04 \%$ dan jumlah skor jawaban "tidak" adalah 62 atau dengan jumlah rata-rata persentase 22,96\%. Berdasarkan hasil yang diperoleh maka dapat disimpulkan bahwa perilaku siswa dalam mengkonsumsi makanan jajanan yang bersih dan sehat di SD Negeri 09 Air Tawar Barat Kec. Padang Utara Kota Padang tergolong cukup, yakni dengan rata-rata persentase 77,04\%.

Untuk lebih jelasnya perilaku siswa tentang mengkonsumsi makanan jajanan yang bersih dan sehat di SD Negeri 09 Air Tawar Barat Kec. Padang Utara Kota Padangdapat dilihat pada gambar histogram di bawah ini:

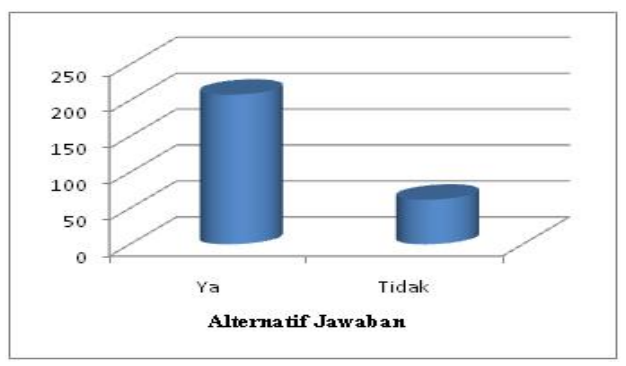

Gambar 3. Perilaku Tentang Mengkonsumsi Makanan Jajanan yang Bersih dan Sehat

\section{Perilaku Tentang Menggunakan Jamban yang Bersih dan Sehat}

Mengenai perilaku tentang menjaga kebersihan dan menggunakan jamban yang sehatdi sekolah di SD Negeri 09 Air Tawar Barat Kec. Padang Utara Kota Padang dilihat dari 2 (dua) indikator, yaitu menjaga kebersihan jamban dan alat yang digunakan untuk menjaga kebersihan jamban. Analisis data deskripsi mendapatkan hasil tentang perilaku menggunakan jamban yang bersih dan sehat. Pertanyaan no 21 sebanyak $52(96,29 \%)$ orang siswa menjawab "ya", dan $2(3,70 \%)$ orang siswa menjawab "tidak", pertanyaan no 22 sebanyak $54(100 \%)$ orang siswa yang menjawab "ya", dan tidak ada siswa yang menjawab "tidak", pertanyaan no 23 sebanyak $30(55,56 \%)$ orang menjawab "ya" dan 24 $(44,44 \%)$ orang menjawab "tidak", pertanyaan no 24 sebanyak $14(25,93 \%)$ orang siswa menjawab "ya" dan $40(74,07 \%)$ orang siswa yang menjawab "tidak", dan pertanyaan no 25 sebanyak 15 $(27,78 \%)$ orang menjawab "ya" dan $39(72,22 \%)$ orang menjawab "tidak".

Berdasarkan analisis di atas, maka dapat disimpulkan hasil distribusi frekuensi data siswa tentang perilaku menggunakan jamban yang bersih dan dari 54orang responden untuk 5 butir pernyataan, jumlah skor jawaban "ya" adalah 165 atau dengan jumlah rata-rata persentase $61,12 \%$ dan jumlah skor jawaban "tidak" adalah 105 atau dengan rata-rata persentase 38,8\%. Berdasarkan hasil yang diperoleh maka dapat disimpulkan bahwa perilaku siswa tentang menggunakan jamban yang bersih dan sehat di sekolah di SD Negeri 09 Air Tawar Barat Kec.Padang Utara Kota Padang tergolong kurang, yakni dengan rata-rata persentase $61,12 \%$. Untuk lebih jelasnya perilaku siswa 
tentang menggunakan jamban yang bersih dan sehat di sekolah di SD Negeri 09 Air Tawar Barat Kec. Padang Utara Kota Padangdapat dilihat pada gambar histogram di bawah ini:

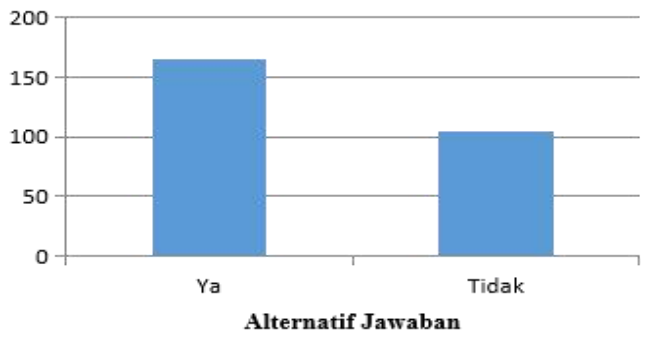

\section{Gambar 4. Perilaku Tentang Menggunakan Jamban yang Bersih dan Sehat \\ 5. Perilaku Tentang Melakukan Olahraga Yang Teratur dan Terukur}

Mengenai perilaku tentang berolahraga yang teratur dan terukurdi sekolah di SD Negeri 09 Air Tawar Barat Kec. Padang Utara Kota Padang dilihat dari 1 (satu) indikator, yaituperilaku melakukan olahrga yang teratur dan terukur. Hasil analisis data menunjukkan tentang perilaku tentang melakukan olahraga yang teratur dan terukur. pertanyaan no 26 sebanyak $53(98,15 \%)$ orang siswa menjawab "ya", dan $1(1,85 \%)$ orang siswa menjawab "tidak", pertanyaan no 27 sebanyak $52(96,29 \%)$ orang siswa yang menjawab "ya", dan $2(3,70 \%)$ orang siswa menjawab "tidak", pertanyaan no 28 sebanyak $29(53,70 \%)$ orang menjawab "ya" dan $25(46,29 \%)$ orang menjawab "tidak", pertanyaan no 29 sebanyak $30(55,56 \%)$ yang menjawab "ya", dan $24(44,44 \%)$ orang siswa menjawab "tidak" ,pertanyaan no 30 sebanyak $45(83,33 \%)$ orang siswa yang menjawab "ya", dan $9(16,67 \%)$ orang siswa yang menjawab "tidak".

Berdasarkan analisis di atas, maka dapat disimpulkan hasil distribusi frekuensi data siswa tentang melakukan olahraga yang teratur dan terukurdi SD Negeri 09 Air Tawar Barat Kec. Padang Utara Kota Padangdari54orang responden untuk 5 butir pernyataan, jumlah skor jawaban "ya" adalah 209 atau dengan jumlah rata-rata persentase $77,41 \%$ dan jumlah skor jawaban "tidak" adalah 61 atau dengan rata-rata persentase $22,59 \%$. Berdasarkan hasil yang diperoleh maka dapat disimpulkan bahwa perilaku siswa tentang melakukan olahraga yang teratur dan terukur di sekolah di SD Negeri 09 Air Tawar Barat Kec. Padang Utara Kota Padang tergolong cukup, yakni dengan rata-rata persentase $77,41 \%$. Untuk lebih jelasnya perilaku siswa tentang melakukan olahraga yang teratur dan terukur di sekolah di SD Negeri 09 Air Tawar Barat Kec. Padang Utara Kota Padangdapat dilihat pada gambar histogram di bawah ini:

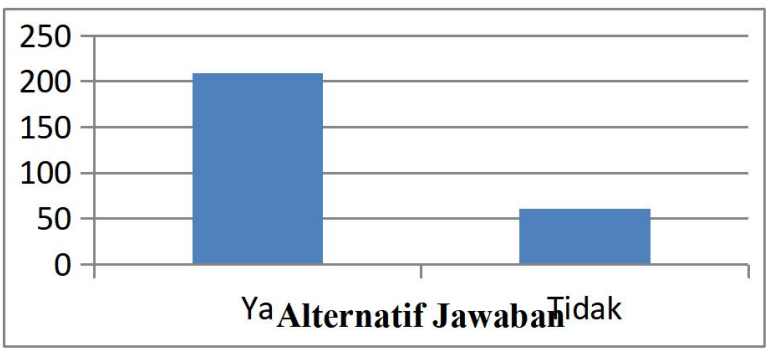

Gambar 5. Perilaku Tentang Melakukan Olahraga yang Teratur dan Terukur

\section{Perilaku Tentang Memberantas Jentik Nyamuk}

Mengenai perilaku memberantas jentik nyamuk di sekolah di SD Negeri 09 Air Tawar Barat Kec. Padang Utara Kota Padang dilihat dari 2 (dua) indikator, yaitu bebas dari nyamuk dan alat pengusir nyamuk serta cara memberantas jentik nyamuk. Selanjutnya analisis data menunjukkan tentang perilaku memberantas jentik nyamuk. Pertanyaan no 31 sebanyak $13(24,07 \%)$ orang siswa menjawab "ya" dan $41(75,93 \%)$ orang siswa yang menjawab "tidak", pertanyaan no 32 sebanyak 21 $(38,89 \%)$ orang menjawab "ya" dan $33(61,11 \%)$ orang menjawab "tidak", pertanyaan no 33 sebanyak $29(53,70 \%)$ orang siswa menjawab "ya", dan $25(46,29 \%)$ orang siswa menjawab "tidak", pertanyaan 
no 34 sebanyak $36(66,67 \%)$ orang siswa yang menjawab "ya", dan $18(33,33 \%)$ orang siswa menjawab "tidak", dan pertanyaan no 35 sebanyak 20 (37,04\%) orang siswa menjawab "ya" dan 34 $(62,96 \%)$ orang siswa menjawab "tidak".

Berdasarkan analisis di atas, maka dapat disimpulkan hasil distribusi frekuensi data siswa tentang memberantas jentik nyamuk di 54 orang responden untuk 5 butir pernyataan, jumlah skor jawaban "ya" adalah 119 atau dengan jumlah rata-rata persentase 44,08\% dan jumlah skor jawaban "tidak" adalah 151 atau dengan rata-rata persentase 55,92\%. Berdasarkan hasil yang diperoleh maka dapat disimpulkan bahwa perilaku memberantas jentik nyamuk di sekolah di SD Negeri 09 Air Tawar Barat Kec. Padang Utara Kota Padang tergolong kurang sekali, yakni dengan rata-rata persentase 44,08\%. Untuk lebih jelasnya perilaku siswa tentang memberantas jentik nyamuk di sekolah dapat dilihat pada gambar histogram di bawah ini:

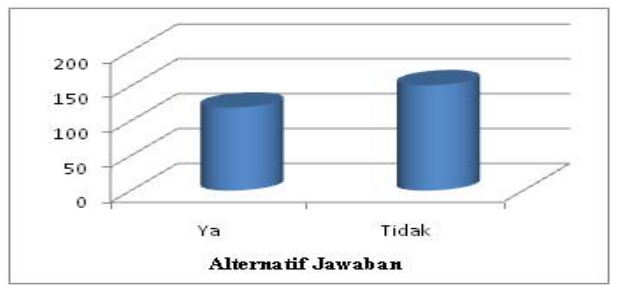

\section{Gambar 6. Perilaku Tentang Memberantas JentikNyamuk}

\section{Perilaku Tidak Merokok di Sekolah}

Mengenai perilaku tidak merokok di sekolah di SD Negeri 09 Air Tawar Barat Kec. Padang Utara Kota Padang dilihat dari 2 (dua) indikator, yaitu perilaku menghindari rokok dan akibat merokok. Analisis data mendapatkan tentang perilaku tidak merokok di sekolah. Pertanyaan no 36 sebanyak 49 (90,74\%) orang siswa menjawab "ya", dan $5(9,25 \%)$ orang siswa menjawab "tidak", pertanyaan no 37 sebanyak $35(64,81 \%)$ orang siswa yang menjawab "ya", dan $19(35,19 \%)$ orang siswa menjawab "tidak", pertanyaan no 38 sebanyak 44 (81,48\%) orang siswa menjawab "ya" dan 10 $(18,52 \%)$ orang siswa menjawab "tidak", pertanyaan no 39 sebanyak $51(94,44 \%)$ orang siswa menjawab "ya", dan 3 (5,56\%) orang siswa menjawab "tidak", dan pertanyaan no 40 sebanyak 46 $(85,19 \%)$ orang siswa yang menjawab "ya", dan $8(14,81 \%)$ orang siswa menjawab "tidak".

Berdasarkan analisis di atas, maka dapat disimpulkan secara keseluruhan hasil distribusi frekuensi data siswa tentang tidak merokok di sekolahdi SD Negeri 09 Air Tawar Barat Kec. Padang Utara Kota Padangdari54orang responden untuk 5 butir pernyataan, jumlah skor jawaban "ya" adalah 225 atau dengan jumlah rata-rata persentase $83,4 \%$ dan jumlah skor jawaban "tidak" adalah 45 atau dengan rata-rata persentase $16,6 \%$. Berdasarkan hasil yang diperoleh maka dapat disimpulkan bahwa perilaku siswa tentang tidak merokok di sekolah di SD Negeri 09 Air Tawar Barat Kec. Padang Utara Kota Padang tergolong baik, yakni dengan rata-rata persentase $83,4 \%$. Untuk lebih jelasnya perilaku siswa tentang tidak merokok di sekolah di SD Negeri 09 Air Tawar Barat Kec. Padang Utara Kota Padangdapat dilihat pada gambar histogram di bawah ini:

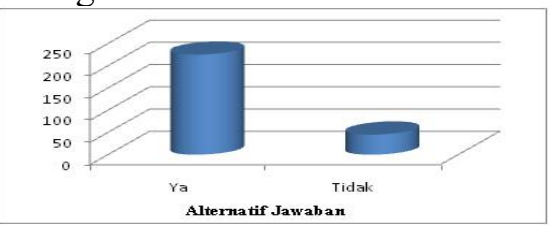

Gambar 7. Perilaku Tidak Merokok

\section{Perilaku Mengukur dan Menimbang Berat Badan Pada Setiap Bulannya}

Mengenai perilaku menimbang berat badan dan mengukur tinggi badan pada setiap bulan di sekolah di SD Negeri 09 Air Tawar Barat Kec. Padang Utara Kota Padang dilihat dari 2 (dua) indikator, yaitu mengetahui berat badan dan tinggi badan setiap bulan dan alat yang digunakan untuk mengukur tinggi badan dan alat untuk menimbang barat badan. Analisa data tentang perilaku 
mengukur tinggi dan menimbang berat badan setiap bulan. Pertanyaan no 41 sebanyak 27 (50\%) orang siswa menjawab "ya", dan $27(50 \%)$ orang siswa menjawab "tidak", pertanyaan no 42 sebanyak 30 $(55,56 \%)$ orang siswa yang menjawab "ya", dan $24(44,44 \%)$ orang siswa menjawab "tidak", pertanyaan no 43 sebanyak $24(44,44 \%)$ orang siswa menjawab "ya" dan $30(55,56 \%)$ orang siswa menjawab "tidak", pertanyaan no 44 sebanyak $40(74,07 \%)$ orang siswa menjawab "ya", dan 14 $(25,93 \%)$ orang siswa menjawab "tidak", dan pertanyaan no 45 sebanyak $32(59,26 \%)$ orang siswa yang menjawab "ya", dan 22 (40,74\%) orang siswa menjawab "tidak".

Berdasarkan analisis di atas, maka dapat disimpulkan secara keseluruhan hasil distribusi frekuensi data siswa tentang perilaku mengukur tinggi dan menimbang berat badan setiap 54 orang responden untuk 5 butir pernyataan, jumlah skor jawaban "ya" adalah 153 atau dengan jumlah ratarata persentase 56,6\% dan jumlah skor jawaban "tidak" adalah 117 atau dengan rata-rata persentase $43,4 \%$. Berdasarkan hasil yang diperoleh maka dapat disimpulkan bahwa perilaku siswa tentang mengukur tinggi dan menimbang berat badan tergolong kurang, yakni dengan rata-rata persentase $56,6 \%$. Untuk lebih jelasnya perilaku siswa tentang mengukur tinggi dan menimbang berat badan di sekolah dapat dilihat pada gambar histogram di bawah ini:

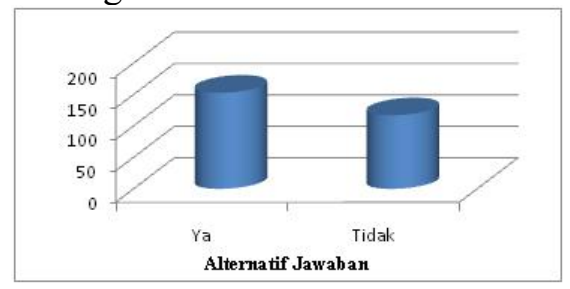

Gambar 8. Perilaku Tentang Mengukur Tinggi dan Menimbang Berat Badan Setiap Bulannya 9. Perilaku Tentang Membuang Sampah Pada Tempatnya

Mengenai perilaku tentang membuang sampah pada tempatnya di sekolah dilihat dari 2 (dua) indikator, yaitu menjaga lingkungan sekolah dan ruang kelas dan tempat membuang sampah. Hasil analisis data melalui distribusi frekuensi menmukan perilaku membuang sampah pada tempatnya. Pertanyaan no 46 sebanyak $42(77,78 \%)$ orang siswa menjawab "ya", dan $12(22,22 \%)$ orang siswa menjawab "tidak", pertanyaan no 47 sebanyak 13 (24,07\%) orang siswa yang menjawab "ya", dan 41 $(75,93 \%)$ orang siswa menjawab "tidak", pertanyaan no 48 sebanyak $7(12,96 \%)$ orang siswa menjawab "ya" dan $41(75,93 \%)$ orang siswa menjawab "tidak", pertanyaan no 49 sebanyak 13 $(24,07 \%)$ orang siswa yang menjawab "ya", dan pertanyaan no 50 sebanyak $53(98,15 \%)$ orang siswa menjawab "ya", dan $1(1,85 \%)$ orang siswa menjawab "tidak".

Berdasarkan analisis di atas, maka dapat disimpulkan secara keseluruhan hasil distribusi frekuensi data siswa tentang perilaku membuang sampah pada tempatnya dari54orang responden untuk 5 butir pernyataan, jumlah skor jawaban "ya" adalah 128 atau dengan jumlah rata-rata persentase $47,40 \%$ dan jumlah skor jawaban "tidak" adalah 142 atau dengan rata-rata persentase $52,60 \%$. Berdasarkan hasil yang diperoleh maka dapat disimpulkan bahwa perilaku siswa dalam membuang sampah pada tempatnya tergolong kurang sekali, yakni dengan rata-rata persentase $47,40 \%$. Untuk lebih jelasnya perilaku siswa dalam membuang sampah pada tempatnya di sekolah dapat dilihat pada gambar histogram di bawah ini:

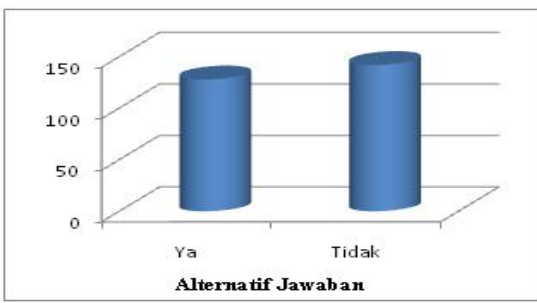

Gambar 10. Perilaku Siswa Tentang Membuang Sampah Pada Tempatnya 
10. Studi Tentang Perilaku Hidup Bersih dan Sehat Siswa di SD Negeri 09 Air Tawar Barat Kec. Padang Utara Kota Padang

Mengenai jawaban keseluruhan responden tentang perilaku hidup bersih dan sehat siswa di sekolah yang terdiri dari 50 butir pertanyaan dan 9 sub variabel, yaitu: perilaku menjaga kesehatan pribadi, perilaku mencuci tangan dengan air yang mengalir dan memakai sabun, perilaku mengkonsumsi makanan jajanan yang bersih dan sehat, perilaku menggunakanjamban yang bersih dan sehat, perilaku berolahraga yang teratur dan terukur, perilaku memberantas jentik nyamuk, perilaku tidak merokok di sekolah, perilaku menimbang berat badan dan mengukur tinggi badan setiap bulan dan perilaku membuangsampah pada tempatnya.

Berdasarkan hasil keseluruhan jawaban responden tentang perilaku hidup bersih dan sehat siswa dapat dapat disimpulkan secara keseluruhan hasil distribusi frekuensi studi tentang perilaku hidup bersih dan sehat siswa dari54 orang responden untuk 50 butir pernyataan, jumlah skor jawaban "ya" adalah 1843 atau dengan jumlah rata-rata persentase $68,25 \%$ dan jumlah skor jawaban "tidak" adalah 857 atau dengan rata-rata persentase $31,75 \%$.

Berdasarkan hasil yang diperoleh maka dapat disimpulkan bahwa studi tentang perilaku hidup bersih dan sehat siswa berada pada klasifikasi cukup, yakni dengan rata-rata persentase $68,25 \%$. Untuk lebih jelasnya studi tentang perilaku hidup bersih dan sehat siswa dapat dilihat pada gambar histogram di bawah ini:

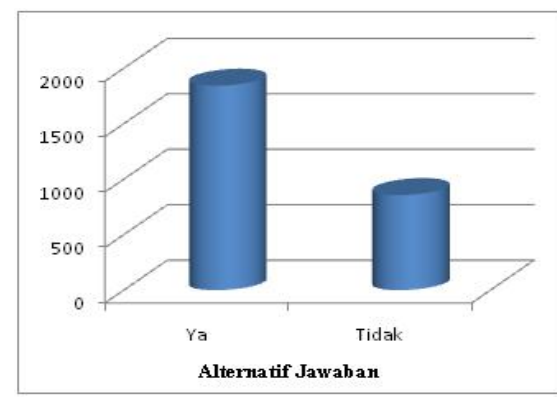

Gambar 11. Studi Tentang Perilaku Hidup Bersih dan Sehat Siswa di Sekolah Dasar Negeri 09 Air Tawar Barat Kec. Padang Utara Kota Padang

\section{Pembahasan}

Penelitian yang dilakukan untuk mengungkap Studi Tentang Perilaku Hidup Bersih dan Sehat Siswa di SD Negeri 09 Air Tawar Barat Kec. Padang Utara Kota Padang. Studi ini dilihat dari aspek PHBS di sekolah, yaitu perilaku menjaga kesehatan pribadi, perilaku mencuci tangan dengan air yang mengalir dan memakai sabun, perilaku mengkonsumsi makanan jajanan yang bersih dan sehat, perilaku menggunakanjamban yang bersih dan sehat, perilaku berolahraga yang teratur dan terukur, perilaku memberantas jentik nyamuk, perilaku tidak merokok di sekolah, perilaku menimbang berat badan dan mengukur tinggi badan setiap bulan dan perilaku membuangsampah pada tempatnya. Untuk lebih jelasnya studi tentang perilaku hidup sehat siswa di sekolah dapat diuraikan sebagai berikut:

\section{Perilaku Menjaga Kesehatan Pribadi}

Temuan penelitian tentang perilaku menjaga kesehatan pribadi siswa di SD Negeri 09 Air Tawar Barat Kec. Padang Utara Kota Padang dilihat dari empat indikator, yaitu perilaku menjaga kesehatan gigi, perilaku menjaga kesehatan kulit, perilaku menjaga kebersihan kuku, dan perilaku menjaga kebersihan pakaian tergolong dalam kategoribaik dengan persentase $81,9 \%$.

Perilaku tentang menjaga kesehatan pribadi siswa di sekolah di SD Negeri 09 Air Tawar Barat Kec. Padang Utara Kota Padang sudah berada pada kategori baik. Hal ini berarti siswa sudah menerapkan perilaku hidup bersih dan sehat dalam menjaga kesehatan pribadi. Perilaku tersebut supaya dipertahankan, sehingga kesehatan pribadi siswa tetap terjaga dan dapat mempertahankan kesehatannya, serta terhindar dari sakit dan penyakit. 


\section{Perilaku Mencuci Tangan dengan Air yang Mengalir dan Memakai Sabun}

Temuan penelitian tentang perilaku siswa dalam mencuci tangan dengan air yang mengalir dan memakai sabun di SD Negeri 09 Air Tawar Barat Kec. Padang Utara Kota Padang tergolong pada kategori cukup dengan persentase $71,85 \%$. Hal ini menandakan siswa masih belum semaksimal mungkin menerapkan perilaku mencuci tangan dengan air yang mengalir dan memakai sabun serta siswa kurang mengetahui manfaat mencuci tangan dengan air yang mengalir dan memakai sabun. Adapun manfaat mencuci tangan menurut Proverawati (2012:73) adalah "mencegah penularan penyakit seperti Diare, Kolera Disentri, Typus, kecacingan, penyakit kulit, Infeksi Saluran Pernafasan Akut (ISPA), dan Flu burung".

Berdasarkan pendapat tersebut maka dapat disimpulkan bahwa mencuci tangan sangat berdampak positif bagi kesehatan tubuh, oleh karena itu perilaku siswa dalam mencuci tangan dengan air yang mengalir dan memakai sabun di SD Negeri 09 Air Tawar Barat Kec. Padang Utara Kota Padang agar ditingkatkan lagi penerapannya, sehingga kesehatan siswa tetap terjaga dan siswa dapat mempertahankan kesehatannya, serta terhindar dari sakit dan penyakit. Hal ini dapat dilakukan dengan cara menyediakan air yang bersih dan mengalir, serta menyediakan sabun untuk mencuci tangan.

\section{Perilaku Mengkonsumsi Makanan Jajanan yang Bersih dan Sehat}

Temuan penelitian tentang perilaku mengkonsumsi makanan jajanan yang bersih dan sehat di SD Negeri 09 Air Tawar Barat Kec. Padang Utara Kota Padang tergolong pada kategori cukupdengan persentase $77,04 \%$. Hal ini berarti siswa masih belum semaksimal mungkin menerapkan perilaku mengkonsumsi makanan jajanan yang bersih dan sehat serta siswa kurang mengetahui syarat-syarat makanan jajanan yang sehat, sebagaimana yang diungkapkan oleh Irianto (2004:74) bahwa syaratsyarat makanan sehat adalah:

“(1) Mudah dicerna oleh alat pencernaan, (2) bersih, tidak mengandung bibit penyakit, karena hal ini tentu akan membahayakan kesehatan tubuh serta tidak bersifat racun bagi tubuh, (3) jumlah yang cukup dan tidak berlebihan, (4) tidak terlalu panas saat dimakan. Makanan yang terlalu panas dimakan, mungkin sekali dapat merusak gigi dan mengunyah pun tidak dapat sempurna, (5) bentuknya menarik dan rasanya enak".

Berdasarkan kutipan di atas dapat disimpulkan bahwa memperhatikan makanan jajanan yang sehat sangat penting demi menghindari penyakit yang datang dari makanan. Oleh karena itu, perilaku siswa tentang mengkonsumsi makanan jajanan yang bersih dan sehat di sekolah di SD Negeri 09 Air Tawar Barat Kec. Padang Utara Kota Padang agar ditingkatkan lagi penerapannya, sehingga makanan jajan yang bersih dan sehat siswa tetap terjaga dan siswa dapat mempertahankan kesehatannya, serta terhindar dari sakit dan penyakit. Hal ini dapat dilakukan dengan cara menyediakan kantin sekolah supaya siswa tidak jajan disembarangan tempat, meningkatkan lagi pengetahuan siswa tentang mengkonsumsi makanan yang bersih dan sehat.

\section{Perilaku Tentang Menggunakan Jamban yang Bersih dan Sehat}

Temuan penelitian tentang perilakumengunakan jamban yang bersih dan sehatdi SD Negeri 09 Air Tawar Barat Kec. Padang Utara Kota Padangtergolong pada kategori kurang dengan persentase $61,12 \%$. Hal ini menandakan kurangnya kebersihan dan kesehatan jamban di sekolah tersebut sehingga perilaku siswa dalam hal menggunakan jamban yang bersih dan sehat menjadi kurang. Oleh karena itu, kebersihan dan kesehatan jamban di sekolah tersebut harus lebih ditingkatkan lagi sehingga siswa mampu berperilaku hidup bersih dan sehat dalam hal menggunakan jamban yang bersih dan sehat sebagaimana yang diungkapkan Proverawati (2012:78) tentang syarat jamban yang sehat adalah:

"(1) tidak mencemari sumber air minum ( jarak antara sumber air minum dengan lubang penampungan minimal 10 meter), (2) tidak berbau, (3) kotoran tidak dapat dijamah oleh serangga dan tikus, (4) tidak mencemari tanah disekitarnya, (5) mudah dibersihkan dan aman digunakan, (6) dilengkapi dinding dan atap pelindung, (7) penerangan dan ventilasi yang 
cukup, (8) lantai kedap air dan luas ruangan memadai, dan (9) tersedia air, sabun, dan alat pembersih lainnya".

Berdasarkan kutipan di atas dapat disimpulkan bahwa syarat jamban yang sehat adalah jamban yang tidak mencemari sumber air minum, tidak berbau, kotoran tidak dapat dijamah oleh serangga dan tikus, tidak mencemari tanah disekitarnya, mudah dibersihkan dan aman digunakan, dilengkapi dinding dan atap pelindung, penerangan dan ventilasi yang cukup, lantai kedap air dan luas ruangan memadai, dan tersedia air, sabun, dan alat pembersih lainnya. Untuk mencapai syarat jamban yang bersih dan sehat di atas dapat dilakukan dengan cara goro bersama membersihkan jamban di sekolah dua minggu sekali, sehingga kebersihan jamban siswa di sekolah tatap terjaga kebersihannya dan siswapun mampu menerapkan perilaku hidup bersih dan sehat dalam hal menggunakan jamban yang bersih dan sehat.

\section{Perilaku Tentang Melakukan Olahraga yang Teratur dan Terukur}

Temuan penelitian tentang perilaku melakukan olahraga yang teratur dan terukur di SD Negeri 09 Air Tawar Barat Kec. Padang Utara Kota Padang tergolong pada kategori cukup dengan persentase 77,41\%.Hal ini menandakan siswa masih belum semaksimal mungkin menerapkan perilaku berolahraga yang teratur dan terukur sebagaimana yang diungkapkan Proverawati (2012:93) "aktifitas fisik dilakukan secara teratur paling sedikit 30 menit dalam sehari, sehingga dapat menyehatkan jantung, paru-paru serta alat tubuh lainnya". Berdasarkan pendapat tersebut, maka dari itu hendaknya memberikan aktifitas fisik kepada siswa tidak hanya pada saat pembelajaran penjasorkes saja, tetapi juga dapat dilakukandengan cara melakukan semam pagi setiap harinya di sekolah sehingga kesehatan siswa tetap terjaga dan siswa dapat mempertahankan kesehatannya, serta terhindar dari sakit dan penyakit.

\section{Perilaku Memberantas Jentik Nyamuk}

Temuan penelitian tentang perilaku memberantas jentik nyamuk di SD Negeri 09 Air Tawar Barat Kec. Padang Utara Kota Padangberada pada kategori kurang sekali dengan persentase 44,08\%. Hal ini menandakan siswa sangat kurang sekali menerapkan perilaku memberantas jentik nyamuk di sekolah tersebut serta siswa tidak mengetahui manfaat terbebas dari nyamuk tersebut. Menurut Proverawati (2012:83-84) manfaat bebas dari nyamuk adalah "memungkinan terhindar dari berbagai penyakit semakin besar, seperti Demam Berdarah Dengue (DBD), Malaria, Cikungunya atau kaki gajah”. Berdasarkan pendapat tersebut, maka dari itu perilaku siswa dalam memberantas jentik nyamuk harus lebih sangat ditingkatkan lagi penerapannya. Hal ini dapat dilakukan dengan cara melakukan 3M, yaitu menguras dan menyikat tempat-tempat penampungan air (seperti bak air yang berada di WC sekolah, tatakan pot, dan lain sebagainya), menutup rapat-rapat tempat penampungan air seperti bak control, lubang pohon dan lekukan-lekukan yang dapat menampung air hujan, mengubur atau menyingkirkan barang-barang bekas yang dapat menampung air seperti ban bekas, kaleng bekas, plastik-plastik yang dibuang sembarangan, serta melakukan goro bersama setiap minggunya.

\section{Perilaku Tidak Merokok di Sekolah}

Temuan penelitian tentang perilaku tidak merokok di sekolah di SD Negeri 09 Air Tawar Barat Kec. Padang Utara Kota Padang berada pada kategoribaik dengan persentase 83,4\%. Hal ini berarti siswa sudah menerapakan perilaku tidak merokok dan perilaku tersebut supaya dipertahankan. Oleh karena itu, diharapkan kepada guru terutama kepada orang tua murid agar selalu mengontrol dan memperhatikan perilaku anaknya untuk menghindari rokok baik di sekolah, di rumah maupun saat berada di luar rumah, sehingga kesehatan siswa tetap terjaga dan dapat mempertahankan kesehatannya, serta terhindar dari sakit dan penyakit.

\section{Perilaku Mengukur Tinggi dan Menimbang Berat Badan Setiap Bulannya}

Temuan penelitian tentang perilaku mengukur tinggi dan menimbang berat badan setiap bulannya di SD Negeri 09 Air Tawar Barat Kec. Padang Utara Kota Padang berada pada kategori kurang dengan persentase $56,6 \%$. Hal ini menandakan kurangnya ketersediaan alat pengukur tinggi 
Sport Science: Jurnal Sain Olahraga dan Pendidikan Jasmani ISSN 114-562X (Cetak), ISSN XXXX-XXXX(Online)

http://sportscience.ppj.unp.ac.id/index.php/jss/index

dan alat penimbang berat badan di sekolah tersebut sehingga perilaku siswa dalam hal mengukur tinggi dan menimbang berat badan setiap bulannya menjadi kurang terlaksanakan. Oleh karena itu, diharapkan kepada pihak sekolah untuk menyediakan alat pengukur tinggi dan alat penimbang berat badan siswa dan menekankan kepada siswa untuk menggunakan fasilitas tersebut, sehingga siswa mampu menerapkan perilaku hidup bersih dan sehat di sekolah dalam hal mengukur tinggi dan menimbang berat badan setiap bulannya. Adapun manfaat mengukur tinggi dan penimbangan berat badan siswa setiap bulan di sekolah menurut Depkes(2002:6) antara lain:

"(1) untuk mengetahui apakah siswa tumbuh sehat, (2) untuk mengetahui dan mencegah gangguan pertumbuhansiswa, (3) untuk mengetahui siswa yang dicurigai gizi kurang dan gizi lebih, sehingga jika ada kelainan yang berpengaruh langsung dalam proses belajar di sekolah, dapat segera dirujuk ke Puskesmas".

Berdasarkan kutipan di atas, mengukur tinggi dan menimbang barat badan pada setiap bulannya sangatlah penting dilakukan karna dapat mengetahui apakah siswa tersebut tumbuh sehat atau tidak dan mengetahui apakah siswa kurang gizi atau tidak. Oleh karena itu, diharapkan kepada guru agar lebih ditekankan lagi penerapan perilaku siswa dalam hal mengukur tinggi dan menimbang barat badan pada setiap bulannya di sekolah di SD Negeri 09 Air Tawar Barat Kec. Padang Utara Kota Padang, sehingga berat dan tinggi badan siswa dapat diketahui demi menghindari kurang gizi dan lambatnya pertumbuhan siswa.

\section{Perilaku Membuang Sampah Pada Tempatnya}

Temuan penelitian tentang perilaku membuang sampah pada tempatnya di SD Negeri 09 Air Tawar Barat Kec. Padang Utara Kota Padang berada pada kategori kurang sekali dengan persentase $47,40 \%$. Hal ini menandakan siswa sangat kurang sekali menerapkan perilaku membuang sampah pada tempatnya di sekolah tersebut serta siswa tidak mengetahui dampak dari membuang sampah sembarangan. Dampak dari membuang sampah sembarangan menurut Proverawati(2012:124) adalah "bersarangnya sumber-sumber penyakit yang dapat menyerang tubuh sehingga mengakibatkan sakit, tersumbatnya aliran air, hal ini menyebebkan terjadinya banjir, tidak sedap dipandang dan lain sebagainya". Oleh karena itu, perilaku siswa dalam hal membuang sampah pada tempatnya agar lebih sangat ditekankan lagi penerapannya, agar nantinya siswa diharapkan lebih dapat meningkatkan perilaku hidup bersih dan sehat dalam hal membuang sampah pada tempatnya. Hal ini dapat dilakukan dengan cara menyediakan tong sampah disetiap ruangan di sekolah tersebut, memberikan sanksi kepada siswa yang membuang sampah sembarangan, dan melakukan goro bersama setiap minggunya.

\section{Perilaku Hidup Bersih dan Sehat Siswa diSD Negeri 09 Air Tawar Barat Kec. Padang Utara Kota Padang}

Dari uraian analisis data diatas, secara umum dapat disimpulkan bahwa Studi Tentang Perilaku Hidup Bersih dan Sehat Siswa diSD Negeri 09 Air Tawar Barat Kec. Padang Utara Kota Padangberada pada kategori cukup dengan persentase $68,25 \%$. Oleh karena itu, perilaku hidup bersih dan sehat siswa di sekolah agar ditingkatkan lagi penerapannya, seperti meningkatkan perilaku dalam menjaga kesehatan pribadi, membiasakan perilaku mencuci tangan dengan air yang mengalir dan memakai sabun setelah melakukan aktifitas, meningkatkan perilaku dalam mengkonsumsi makanan jajanan yang bersih dan sehat, perilaku menggunakanjamban disekolah serta menjaga kebersihan jamban, perilaku berolahraga yang teratur dan terukur, perilaku memberantas jentik nyamuk di sekolah secara rutin, perilaku tidak merokok di sekolah, perilaku menimbang berat badan dan mengukur tinggi badan setiap bulan, dan perilaku membuangsampah pada tempatnya.

Penerapan perilaku hidup bersih dan sehat di sekolah sangat bermanfaat bagi siswa, guru dan masyarakat lingkungan sekolah sebagaimana yang diungkapkan oleh Proverawati (2012:23-24) manfaat pembinaan perilaku hidup bersih dan sehat adalah:

"(1) terciptanya sekolah yang bersih dan sehat sehingga siswa, guru dan masyarakat lingkungan sekolah terlindung dari berbagai gangguan dan ancaman penyakit,(2) 
meningkatkan semangat proses belajar mengajar yang berdampak pada prestasi belajar siswa,(3) citra sekolah sebagai institusi pendidikan semakin meningkat sehingga mampu menarik minat orang tua,(4) meningkatkan citra pemerintah daerah di bidang pendidikan, (5) menjadi percontohan sekolah sehat bagi daerah lain".

Berdasarkan kutipan diatas dapat disimpulkan bahwa pembinaan perilaku hidup bersih dan sehat di sekolah membawa dampak yang positif bagi sekolah tersebut, selain masyarakat sekolah terlindungi dari berbagai macam ancaman penyakit, pembinaan perilaku hidup sehat di sekolah juga dapat meningkatkan semangat belajar dan prestasi belajar siswa, menjadi contoh teladan bagi sekolah lain, dan dapat meningkatkan citra sekolah di mata masyarakat. Dengan penerapan perilaku hidup bersih dan sehat di sekolah oleh siswa, guru dan masyarakat lingkungan sekolah, maka akan membentuk mereka untuk memiliki kemampuan dan kemandirian dalam mencegah penyakit, meningkatkan kesehatannya, serta berperan aktif dalam mewujudkan lingkungan sekolah yang sehat.

\section{KESIMPULAN}

Berdasarkan hasil Studi Tentang Perilaku Hidup Bersih dan Sehat Siswa di SD Negeri 09 Air Tawar Barat Kec. Padang Utara Kota Padang yang telah dilaksanakan dapat disimpulkan bahwa Perilaku tentang menjaga kesehatan pribadi siswa dikategorikan baik. Perilaku mencuci tangan dengan air yang mengalir dan memakai sabun di sekolah berada pada kategori cukup. Sedangkan Perilaku tentang mengkonsumsi makanan jajanan yang sehat di sekolah berada pada kategori cukup. Perilaku tentang menggunakan jamban yang bersih dan sehat di sekolah pada kategori kurang. Perilaku tentang berolahraga yang teratur dan terukur dikategorikan cukup. Perilaku tentang memberantas jentik nyamuk di sekolah berada pada kategori kurang sekali.

Selanjutnya perilaku tentang tidak merokok di sekolah dikategorikan baik. Perilaku tentang menimbang berat dan tinggi badan pada setiap bulannya dikategorikan kurang. Perilaku membuang sampah pada tempatnya dikategorikan kurang sekali. Secara umum dapat disimpulkan bahwa Studi Tentang Perilaku Hidup Bersih dan Sehat Siswa berada pada kategori cukup. Berdasarkan tujuan penelitian ini, maka peneliti mengemukakan pendapat bahwa perilaku tentang menjaga kesehatan pribadi siswa dan perilaku tentang tidak merokok di sekolah dikategorikan baik, supaya tetap dipertahankan. Perilaku mencuci tangan dengan air yang mengalir dan memakai sabun di sekolah, perilaku tentang mengkonsumsi makanan jajanan yang sehat di sekolah dan perilaku tentang berolahraga yang teratur dan terukur berada pada kategori cukup, agar ditingkatkan lagi.

Perilaku tentang menggunakan jamban yang bersih dan sehat di sekolah dan perilaku tentang menimbang berat dan tinggi badan pada setiap bulannya di sekolah berada pada kategori kurang, agar lebih ditekankan lagi. Perilaku tentang memberantas jentik nyamuk di sekolah dan perilaku membuang sampah pada tempatnya di sekolah pada kategori kurang sekali, agar lebih sangat ditekankan lagi penerapannya terhadap siswa. Secara umum dapat disimpulkan bahwa Studi Tentang Perilaku Hidup Bersih dan Sehat Siswa di SD Negeri 09 Air Tawar Barat Kec. Padang Utara Kota Padang berada pada kategori cukup, agar ditingkatkan lagi. Diharapkan kepada guru untuk memberikan pengetahuan tentang pentingnya perilaku hidup bersih dan sehat kepada siswa-siswanya. Kepada siswa agar lebih memperhatikan dan meningkatkan perilaku hidup bersih dan sehat baik di sekolah maupun dalam kehidupan sehari-hari.

\section{DAFTAR RUJUKAN}

A,Muri Yusuf. (2005). Metodologi Penelitian. Padang: UNP Press.

Arikunto, Suharsimi. (2006). Prosedur Penelitian Suatu Penelitian Praktik. Jakarta: PT Asdi Mahasatya. 
Sport Science: Jurnal Sain Olahraga dan Pendidikan Jasmani ISSN 114-562X (Cetak), ISSN XXXX-XXXX(Online)

http://sportscience.ppj.unp.ac.id/index.php/jss/index

Dame, Melva. (2009). Tindakan Murid dan Penjual Makanan Jajanan Tentang Higiene Sanitasi Makanan di Sekolah Dasar. Medan: USU.

Depdikbud. (1986). Tuntunan Pendidikan Kesehata Pribadi. Jakarta: Depdikbud.

Depdiknas. (2008). Kamus Besar Bahasa Indonesia. Jakarta: PT Gramedia Pustaka Umum.

Depdiknas UNP. (2009). Buku Panduan Penulisan Tugas Akhir/Skripsi UNP.

Padang: Depdiknas UNP.

Depkes RI. (2002). Cara Melaksanakan Usaha Kesehatan Sekolah di Sekolah Dasar. Jakarta: Depkes RI.

Ichsan, M. (1988). Pendidikan Kesehatan dan Olahraga. Jakarta: Depdikbud.

Irianto, Kus. (2004). Gizi dan Pola Hidup Sehat. Bandung: CV Yrama Widya.

Marjohan. (2009). Penunjang Mata Kuliah Penelitian. Padang: UNP Press.

Mu'rifah. (1992). Pendidikan Kesehatan. Jakarta: Dupdikbud.

Notoatmodjo. (2003). Ilmu Kesehatan Masyarakat Prinsip-prinsip Dasar. Jakarta: Rineka Cipta.

Proverawati, Atikah dan Eni Rahmawati. (2012). Perilaku Hidup Bersih dan Sehat. Jakarta: Nuha Medika.

Ridwan. (2006). Belajar Mudah Penelitian. Bandung: ALFABETA.

Soeaidy, Sholeh. (1996). Himpunan Peraturan Kesehatan. Jakarta: Arcan.

Sudjana.(1992). Metode Statistik. Bandung: Tarsito.

Tim Esensi. (2012). Mengenal UKS. Jakarta: PT. Gelora Aksara Pratama.

Tjitarsa, Ida Bagus. (1992). Pendidikan Kesehatan. Bandung: ITB dan Universitas Udayana. 